Miloš Vesić, potporučnik, dipl. inž. VP 8080-18, Beograd mr Slavko Muždeka, kapetan I klase, dipl. inž.
Vojna akademija, Beograd

\section{ANALIZA UTICAJA KINEMATSKE ŠEME SISTEMA ZA ZAOKRET BRZOHODNIH GUSENIČNIH VOZILA NA BILANS SNAGE U ZAOKRETU}

UDC: 623.437 .425

623.438 .3

Rezime:

U radu je izvršena analiza bilansa snage u zaokretu za tipične predstavnike simetričnih i nesimetričnih sistema za zaokret sa dva toka snage. Na osnovu analize aktivnih sila i brzina premotavanja gusenica u funkciji od poluprečnika zaokreta, dobijene su potrebne snage na gusenicama za realizaciju zaokreta u zadatim uslovima. Za svaki sistem za zaokret definisana su funkcionalna stanja i tokovi snage u svakom od njih. Izvršena je uporedna analiza bilansa snage u zaokretu za simetrični $i$ nesimetrični sistem sa istim performansama pravolinijskog kretanja radi sagledavanja uticaja kinematske šeme na vučne performanse. Pokazano je da kinematska šema sistema za zaokret znatno utiče na vučne performanse zaokreta $i$ da kod simetričnih sistema postoje veći gubici snage i veća potreba za snagom motora.

Ključne reči: gusenično vozilo, sistem za zaokret, kinematska šema, bilans snage.

\title{
ANALYSIS OF INFLUENCE OF TURNING SYSTEM KINEMATIC SCHEME ON TURNING POWER BALANCE FOR HIGH SPEED TRACKED VEHICLES
}

Summary:

The analysis of turning power balance for symmetric and nonsymmetrical turning systems of tracked vehicles has been considered in the paper. The necessary power of tracks for required radius of turn has been determined on the base of analysis of active forces and track velocity accordance to radius of turn. Functional conditions and power flow have been defined for each turning system. The comparative analysis of turning power balance for symmetric and nonsymmetrical turning system with equal tracked performances has been fulfilled and the influence of kinematic scheme on turning tracked performances has been explained. The analysis has showed influence of kinematic scheme on turning tracked performances. The symmetric turning systems worked with higher power losses hence the higher power of vehicle engine is required.

Key words: tracked vehicle, turning system, kinematic scheme, power balance.

\section{Uvod}

Kod brzohodnih guseničnih vozila, pored vučnih performansi pravolinijskog kretanja, interesantne su i vučne performanse zaokreta pošto se zaokret izvodi obezbeđivanjem različitih brzina premotavanja gusenica. Kinematska šema sistema za zaokret ima značajan uticaj na ostvarivanje željenih vučnih performansi zaokreta. Kod starijih realizacija sistema za zaokret brzohodnih guseničnih vozila u primeni su bili sistemi sa jednim tokom snage koji su obezbeđivali skromne vučne performanse, uz znatno klizanje frikcionih elemenata. Uvođenjem sistema za zaokret sa dva toka snage dolazi do znatnog poboljšanja vučnih performansi zao- 
kreta, a omogućava se i racionalno uvođenje hidrostatičkih komponenata. U radu će se analizirati uticaj kinematske šeme sistema za zaokret na bilans snage $u$ zaokretu za najčešće realizacije sistema sa dva toka snage. Analiza će se vršiti za čitav dijapazon poluprečnika zaokreta, od zaokreta oko gusenice do pravolinijskog kretanja.

\section{Kinematske konfiguracije sistema za zaokret sa dva toka snage}

Na slici 1 prikazana je blok-šema sistema za prenos snage koji ima sistem za zaokret sa dva toka snage. Osnovne komponente sistema za prenos snage su menjački prenosnik (MP), sistem za zaokret (SZ) koji se sastoji od pomoćnog pogona (PP) i sumirajućeg planetarnog prenosnika (SPP) i bočni prenosnik (BP). Snaga se prenosi na pogonski točak (PT) guseničnog kretača. U opštem slučaju, kod pravolinijskog kretanja snaga se može prenositi istovremeno glavnim pogonom (gp) i pomoćnim pogonom (pp), ali je to retko, zbog problema vezanih za cirkulaciju snage u zatvorenom kolu PP-MPSPP.

Najčešći slučaj je da se pri pravolinijskom kretanju snaga prenosi samo glavnim pogonom. Pomoćni pogon uključuje se isključivo pri zaokretu. Prisustvo dva toka snage u zaokretu - glavnog i pomoćnog obezbeđuje različite brzine premotavanja gusenica.

Kinematska konfiguracija sumirajućeg planetarnog prenosnika bitno utiče na performanse vozila. Kod savremenih BGV najčešće su u pitanju dve kinematske konfiguracije, kao na slici 2.

Kinematska konfiguracija, prikazana na slici 2a, češće se primenjuje zbog toga što pri pravolinijskom kretanju obezbeđuje redukciju, čime se obezbeđuje da menjački prenosnik bude dimenzionisan prema manjem momentu. Konfiguracija prikazana na slici $2 b$ obezbeđuje kompaktnu konstrukciju sistema za prenos snage, tako da je našla primenu kod uspešnih realizacija sistema za prenos snage BGV [1].

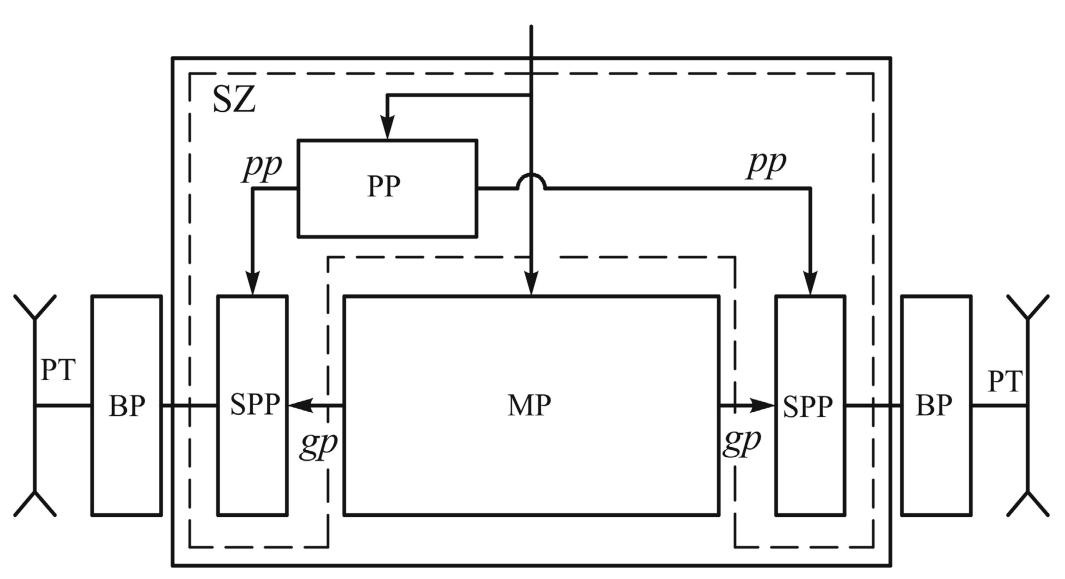

Sl. 1 - Blok-šema sistema za zaokret sa dva toka snage 


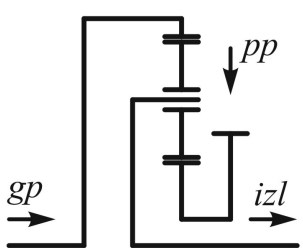

a)

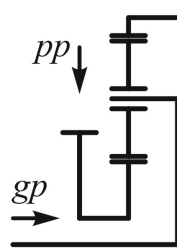

b)
Sl. 2 - Najčešće kinematske konfiguracije sumirajućeg planetarnog prenosnika

Kinematska konfiguracija pomoćnog pogona može da obezbedi tzv. „,simetričan“ ili „nesimetričan“ zaokret. Kod simetričnog zaokreta brzina kretanja težišta vozila prilikom ulaska u zaokret se ne menja, dok kod nesimetričnog zaokreta dolazi do njene promene - najčešće brzina spoljašnje gusenice ostaje nepro- menjena, tako da u zaokretu dolazi do smanjenja brzine kretanja vozila. Na slici 3 prikazane su brzine gusenica pri pravolinijskom kretanju i zaokretu za simetričan i za nesimetričan sistem. Analitički izrazi za brzine premotavanja gusenica $u$ funkciji brzine pre ulaska $\mathrm{u}$ zaokret $\mathrm{v}_{0}$ prikazani su u tabeli 1 .

Kod nesimetričnih sistema pomoćni pogon najčešće je realizovan u vidu jednostepenog prenosnika sa dva frikciona elementa za svaku gusenicu, dok je kod simetričnih sistema pomoćni pogon najčešće realizovan u vidu tzv. „nultog“ vratila sa jednostepenim prenosnikom u pomoćnom pogonu i po jednim frikcionim elementom za zaokret u svaku stranu.

Tabela 1

Brzine premotavanja gusenica

\begin{tabular}{|c|c|c|}
\hline Vrsta sistema & Nesimetričan & Simetričan \\
\hline $\begin{array}{c}\text { Brzina premotavanja unutrašnje } \\
\text { gusenice }\end{array}$ & $\mathrm{v}_{1}=\frac{\mathrm{R}-\mathrm{B}}{\mathrm{R}} \cdot \mathrm{v}_{0}$ & $\mathrm{v}_{1}=\mathrm{v}_{0} \cdot \frac{2 \cdot(\mathrm{R}-\mathrm{B})}{2 \cdot \mathrm{R}-\mathrm{B}}$ \\
\hline $\begin{array}{c}\text { Brzina premotavanja spoljašnje } \\
\text { gusenice }\end{array}$ & $\mathrm{v}_{2}=\mathrm{v}_{0}$ & $\mathrm{v}_{2}=\mathrm{v}_{0} \cdot \frac{2 \cdot \mathrm{R}}{2 \cdot \mathrm{R}-\mathrm{B}}$ \\
\hline
\end{tabular}

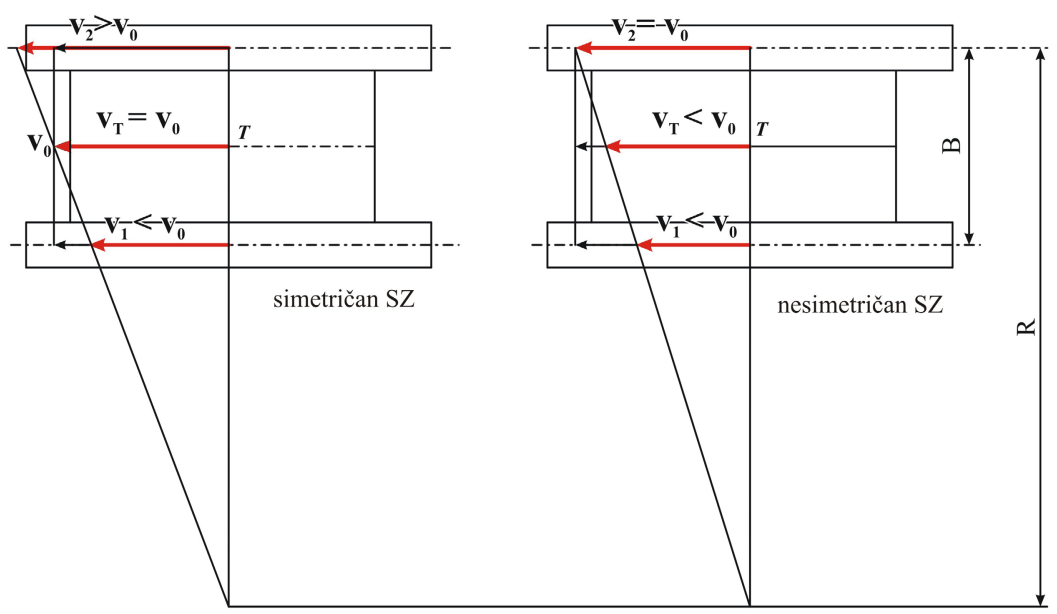

Sl. 3 - Brzine kretanja vozila u zaokretu 
U radu će se razmatrati dve ekvivalentne konfiguracije sistema za prenos snage koje se razlikuju samo u primenjenom sistemu za zaokret. Kao primer nesimetričnog sistema uzet je sistem za prenos snage brzohodnog guseničnog vozila BVP M80A [2]. Kinematska konfiguracija simetričnog sistema dobijena je tako što je razmatranom nesimetričnom sistemu pomoćni pogon zamenjen nultim vratilom. Na slici 4 prikazane su kinematske šeme razmatranih sistema.
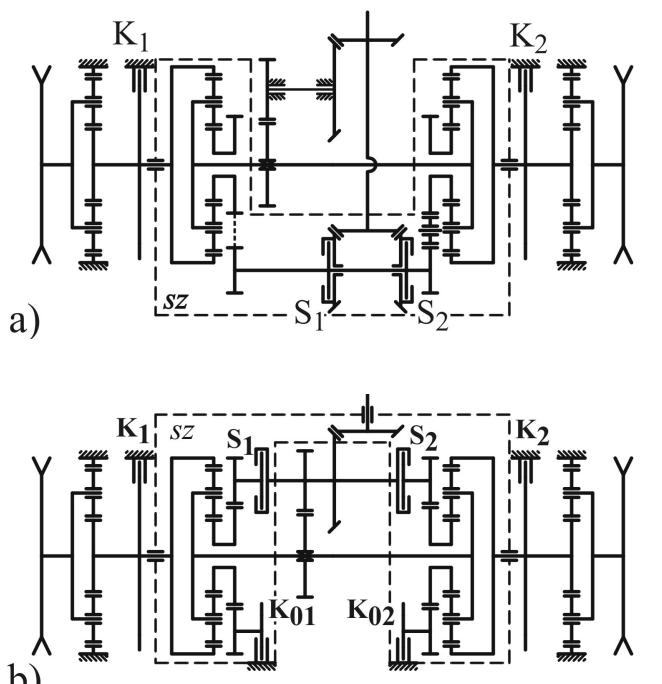

b)

Sl. 4 - Kinematske konfiguracije razmatranih sistema za zaokret

a) simetričan sistem; b) nesimetričan sistem

\section{Bilans snage u zaokretu}

Bilans snage guseničnog vozila $u$ zaokretu pokazuje odnos snage potrebne za savladavanje spoljašnjih otpora, snage motora potrebne za izvođenje zaokreta i raspoložive snage u funkciji poluprečnika zaokreta. Proračunski uslovi za određivanje bilansa snage su [3, 4]:

- zaokret vozila je ravnomeran, bez ubrzavanja i usporavanja i izvodi se na horizontalnoj podlozi;
- raspored specifičnih pritisaka duž kontaktne površine gusenice na ravnoj podlozi je pravougaoni;

- razmatraju se teorijske brzine i poluprečnici zaokreta bez uzimanja u obzir klizanja i proklizavanja gusenica;

- koeficijent prijanjanja i koeficijent otpora kotrljanja su konstantni, i

- otpor vazduha se zanemaruje zbog relativno male brzine kretanja i veličine ostalih otpora.

Pored navedenih pretpostavki potrebno je naglasiti da brzina vozila pre ulaska u zaokret odgovara maksimalnoj brzini kretanja u datom stepenu prenosa.

Da bi se odredio bilans snage u zaokretu, pored brzina premotavanja gusenica, potrebno je poznavati i sile koje deluju na gusenično vozilo pri zaokretu. Šema sila koje deluju na gusenično vozilo u zaokretu za navedene uslove prikazana je na slici 5.

Na slici 5 prikazane su sledeće sile i momenti: potrebne sile na gusenicama za savladavanje otpora $\left(F_{1}, F_{2}\right)$, otpori pravolinijskog kretanja $\left(\mathrm{R}_{1}, \mathrm{R}_{2}\right)$, bočne sile otpora gusenica u zaokretu $\left(\mathrm{S}_{1}, \mathrm{~S}_{2}\right)$ i moment otpora zaokretu $\left(\mathrm{M}_{\mathrm{c}}\right)$ koji je posledica bočnih sila.

Snaga motora potrebna za izvođenje zaokreta $\mathrm{P}_{\mathrm{mz}}$ definiše se sledećim izrazom:

$P_{m z}=P_{o}+P_{t r}+P_{k l}$

gde je:

- $\mathrm{P}_{0}$ - snaga potrebna za savladavanje spoljašnjih otpora,

- $\mathrm{P}_{\mathrm{tr}}$ - snaga potrebna za savladavanje unutrašnjih otpora u elementima sistema za prenos snage i guseničnom kretaču, 


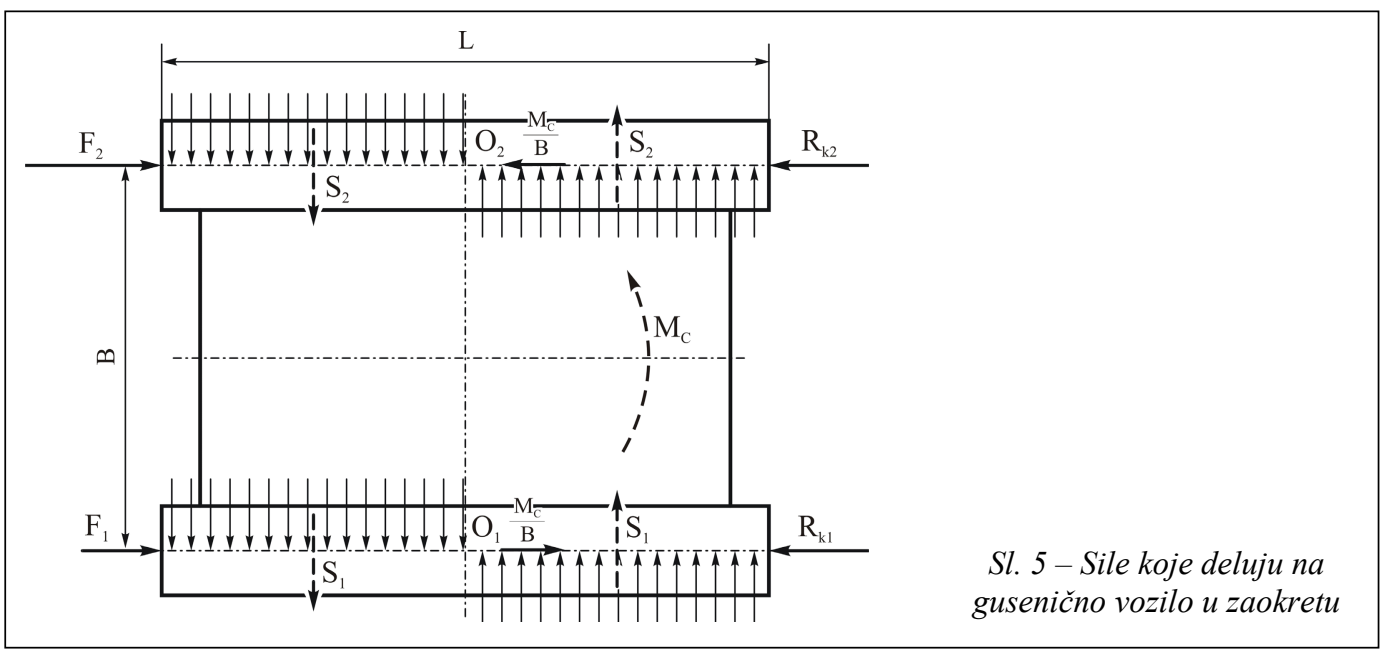

- $\mathrm{P}_{\mathrm{kl}}$ - snaga koja se troši na klizanje $\mathrm{i}$ proklizavanje $\mathrm{u}$ frikcionim elementima (snaga klizanja).

Snaga potrebna za savladavanje spoljašnjih otpora izračunava se prema izrazu [4].

$P_{0}=F_{2} v_{2}+F_{1} v_{1}$

Potrebne sile na gusenicama za ostvarivanje zaokreta $u$ zadatim uslovima izračunavaju se prema sledećim izrazima:

$F_{1}=R_{k 1}-\frac{M_{C}}{B}=f \cdot \frac{G}{2}-\mu \cdot \frac{G \cdot L}{4 \cdot B}$

$\left.F_{2}=R_{k 2}+\frac{M_{C}}{B}=f \cdot \frac{G}{2}+\mu \cdot \frac{G \cdot L}{4 \cdot B}\right\}$

gde je:

$\mathrm{f}$ - koeficijent otpora kotrljanja,

$\mathrm{G}$ - težina vozila,

$\mu$ - koeficijent otpora zaokretu,

L - dužina kontaktne površine gusenice,

$\mathrm{B}$ - širina traga vozila.

Koeficijent otpora zaokretu nije konstantan i izračunava se prema izrazu $\mu=\frac{\mu_{\max }}{\mathrm{a}(1-\mathrm{a}) \frac{\mathrm{R}}{\mathrm{B}}}$, gde je a opitni koeficijent.
Zbog toga i potrebne sile na gusenicama zavise od poluprečnika zaokreta (slika 6).

$\mathrm{Na}$ osnovu izraza za brzine premotavanja gusenica i izraza (3) za potrebne sile na gusenicama za izvođenje zaokreta dobijaju se konačni izrazi za snagu $\mathrm{P}_{0}$

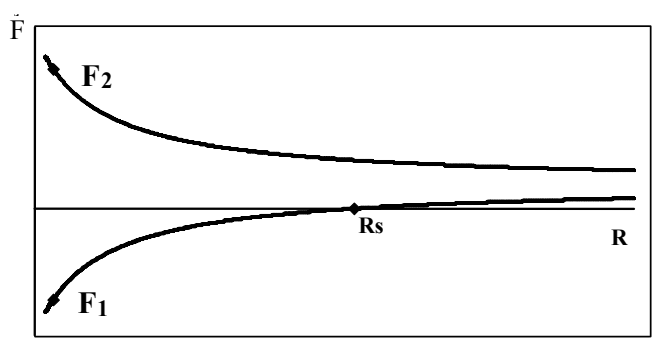

Sl. 6-Potrebne sile na gusenicama pri izvođenju zaokreta

a) za simetričan sistem

$$
P_{0}=\frac{2 \cdot R \cdot\left(F_{2}+F_{1}\right)-2 \cdot B \cdot F_{1}}{2 \cdot R-B} \cdot v_{0}
$$

b) za nesimetričan sistem

$$
P_{0}=\frac{\left(F_{2}+F_{1}\right) \cdot R-F_{1} \cdot B}{R} \cdot v_{0}
$$

Gubici snage u sistemu za prenos snage i guseničnom kretaču opisuju se stepe- 
nom korisnog dejstva po tokovima snage $\mathrm{u}$ određenom funkcionalnom stanju. Pošto su tokovi snage za različita funkcionalna stanja različiti, stepen korisnosti određuje se na osnovu parcijalnih stepena korisnosti pojedinih agregata koji su prikazani na slici 7 . Pored stepena korisnosti na slici su prikazani i prenosni odnosi (i), karakteristike sumirajućih planetarnih prenosnika (k), kao i parametri pogonskog točka guseničnog kretača - broj zubaca z i korak $t_{\mathrm{g}}$, potrebni za analizu zaokreta.

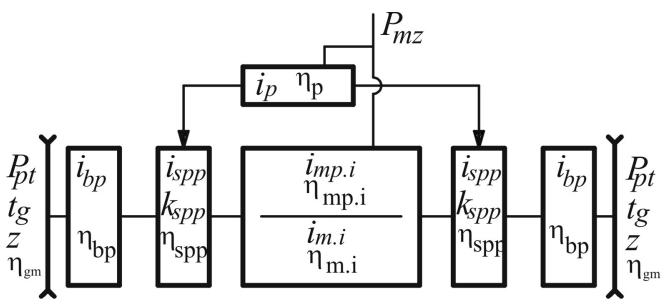

Sl. 7 -Parametri sistema za prenos snage

Stepen korisnosti guseničnog kretača je veličina koja ima znatan uticaj na bilans snage. Postoje različiti izrazi za njegovo izračunavanje, a u ovom radu koristiće se empirijski izraz [5]

$\eta_{g m}=0,95-0,005 v$

gde je:

$\mathrm{v}$ - brzina premotavanja gusenice $\mathrm{u} \mathrm{km} / \mathrm{h}$.

Snaga klizanja se u opštem slučaju određuje prema izrazu:

$P_{k l}=M \cdot \Delta \omega$

gde je:

M - moment koji prenosi (apsorbuje) frikcioni sklop,

$\Delta \omega$ - razlika ugaonih brzina pogonskih i gonjenih elemenata frikcionih sklopova.

Da bi se odredila snaga $P_{k l}$ potrebno je poznavati opterećenja i ugaone brzine na frikcionim elementima koji obezbeđuju izvođenje zaokreta u svim funkcionalnim stanjima sistema za zaokret. Zbog toga je po- trebno analizirati sisteme za zaokret i odrediti funkcionalna stanja $\mathrm{i}$ njihove domene $\mathrm{u}$ funkciji poluprečnika zaokreta. Funkcionalno stanje sistema za zaokret određeno je dijapazonom poluprečnika zaokreta u kome je aktiviran određeni frikcioni element (od delimičnog do potpunog aktiviranja). Za određivanje tokova snage unutar sistema za zaokret važno je i kakva je priroda aktivnih sila potrebnih za izvođenje zaokreta (slika 6). Sila na spoljašnjoj gusenici uvek je pozitivna i realizuje se kao vučna, dok sila na unutrašnjoj gusenici može biti, zavisno od poluprečnika zaokreta, vučna, jednaka nuli ili kočna. U tabeli 2 prikazana su funkcionalna stanja razmatranih sistema za zaokret i predznak aktivne sile na unutrašnjoj gusenici.

Tabela 2

Funkcionalna stanja sistema za zaokret

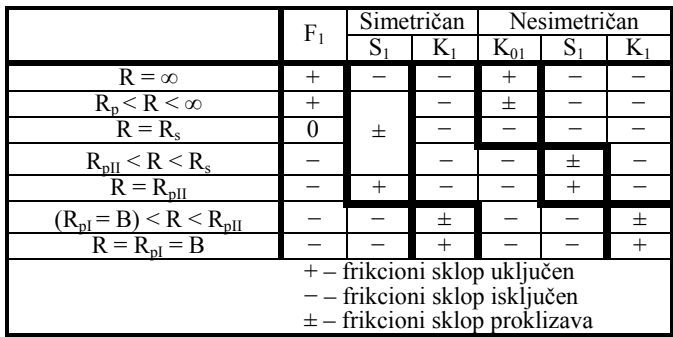

Na osnovu tabele 2 zaključuje se da simetrični sistem za zaokret ima dva funkcionalna stanja koja su određena aktiviranjem spojnice $S_{1}$ i kočnice $K_{1}$ na unutrašnjoj gusenici. Kod nesimetričnog sistema ostvaruju se tri funkcionalna stanja - prvo isključivanjem kočnice $\mathrm{K}_{01}$, drugo uključivanjem spojnice $\mathrm{S}_{1}$, a treće uključivanjem kočnice $\mathrm{K}_{1}$.

$\mathrm{Za}$ određivanje tokova snage potrebno je poznavati i granične poluprečnike funkcionalnih stanja kod kojih su frikcioni elementi potpuno aktivirani. Ti poluprečnici nazivaju se proračunskim i određuju najpovoljnije uslove rada frikcionih elemenata. Oba razmatrana sistema obezbeđuju u svakom stepenu prenosa po jedan proračunski poluprečnik koji je jed- 
Proračunski poluprečnici zaokreta

\begin{tabular}{|c|c|c|}
\hline Vrsta sistema & Nesimetričan & Simetričan \\
\hline Proračunski poluprečnik zaokreta & $\mathrm{R}_{\mathrm{PII}}=\frac{\left(1+\mathrm{k}_{\mathrm{spp}}\right) \cdot \mathrm{i}_{\mathrm{p}}}{\mathrm{i}_{\mathrm{m}}} \cdot \mathrm{B}$ & $\mathrm{R}_{\mathrm{PII}}=\frac{\left(1+\mathrm{k}_{\mathrm{spp}}\right) \cdot \mathrm{i}_{\mathrm{p}}+\mathrm{i}_{\mathrm{m}}}{2 \cdot \mathrm{i}_{\mathrm{m}}} \cdot \mathrm{B}$ \\
\hline
\end{tabular}

nak širini traga $R_{p I}=B$ i po jedan proračunski poluprečnik koji zavisi od veličine prenosnog odnosa u menjačkom prenosniku i unutrašnjeg prenosnog odnosa sumirajućeg planetarnog prenosnika. $U$ tabeli 3 dati su izrazi za određivanje tog proračunskog poluprečnika zaokreta za razmatrane sisteme.
Na osnovu potrebnih aktivnih sila na gusenicama i parametara guseničnog kretača i sistema za prenos snage određuje se moment na frikcionim elementima, a na osnovu brzina premotavanja gusenica i ugaone brzine na ulazu u sistem za prenos snage - ugaone brzine elemenata frikcionih prenosnika. Konačni izrazi za snagu klizanja dati su sledećim izrazima:

a) za simetričan sistem

$$
\mathrm{P}_{k l}= \begin{cases}\frac{1}{i_{p} \cdot \eta_{p} \cdot \eta_{b p}} \cdot\left(\frac{F_{2}}{\eta_{g m .2}}-\frac{F_{1}}{\eta_{g m .1}}\right) \cdot\left(\frac{i_{m}}{1+k_{s p p}}-i_{p} \cdot \frac{B}{2 \cdot R-B}\right) \cdot v_{0}, & \text { za } R>R_{P} \\ \frac{F_{1} \cdot \eta_{m}}{\eta_{t r} \cdot \eta_{g m .1}} \cdot \frac{2 \cdot(R-B)}{2 \cdot R-B} \cdot v_{0}, & \text { za } B<R<R_{P}\end{cases}
$$

b) za nesimetričan sistem

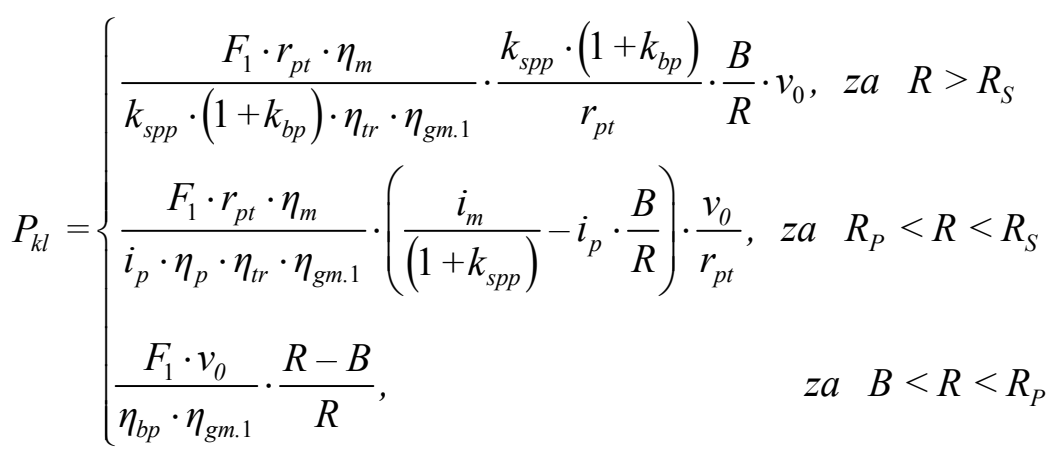

Na osnovu izraza (2), (4), (5), (8) i (9) dobijaju se konačni izrazi za snagu motora potrebnu za izvođenje zaokreta:

a) za simetričan sistem

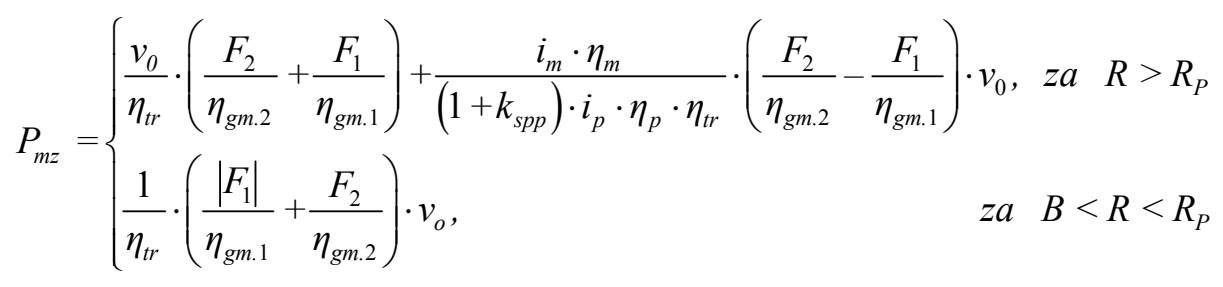


b) za nesimetričan sistem

$$
\begin{aligned}
& \left(\frac{1}{\eta_{t r}} \cdot\left(\frac{F_{1}}{\eta_{g m .1}}+\frac{F_{2}}{\eta_{g m .2}}\right) \cdot v_{0}, \quad R>R_{S}\right. \\
& P_{m z}=\left\{\frac{v_{0}}{\eta_{t r}} \cdot\left(\frac{F_{2}}{\eta_{g m .2}}+\frac{F_{1}}{\eta_{g m .1}}\right)+\frac{i_{m} \cdot F_{1} \cdot v_{0} \cdot \eta_{m}}{\left(1+k_{s p p}\right) \cdot i_{p} \cdot \eta_{p} \cdot \eta_{t r} \cdot \eta_{g m .1}}, \text { za } \quad R_{P}<R<R_{S}\right. \\
& \frac{F_{2} \cdot v_{0}}{\eta_{t r} \cdot \eta_{g m .2}}
\end{aligned}
$$
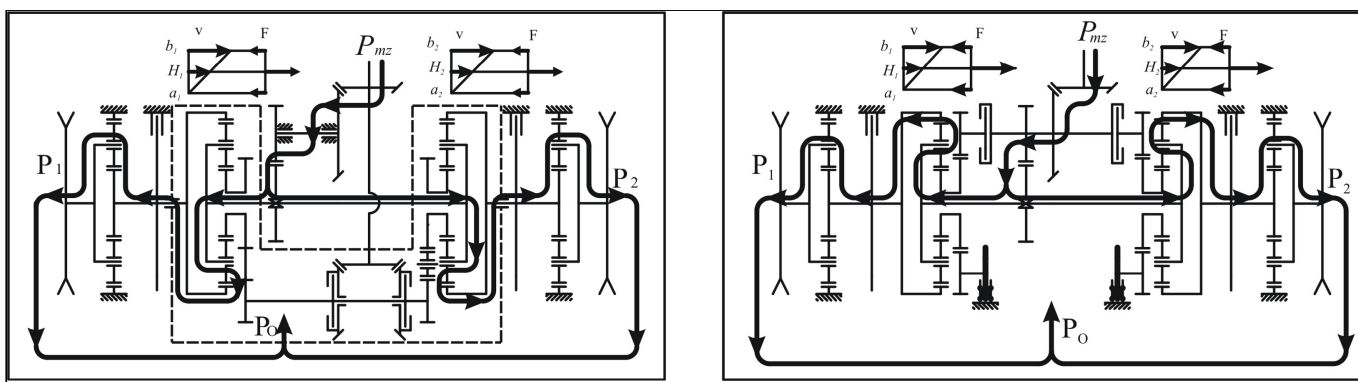

a) pravolinijsko kretanje
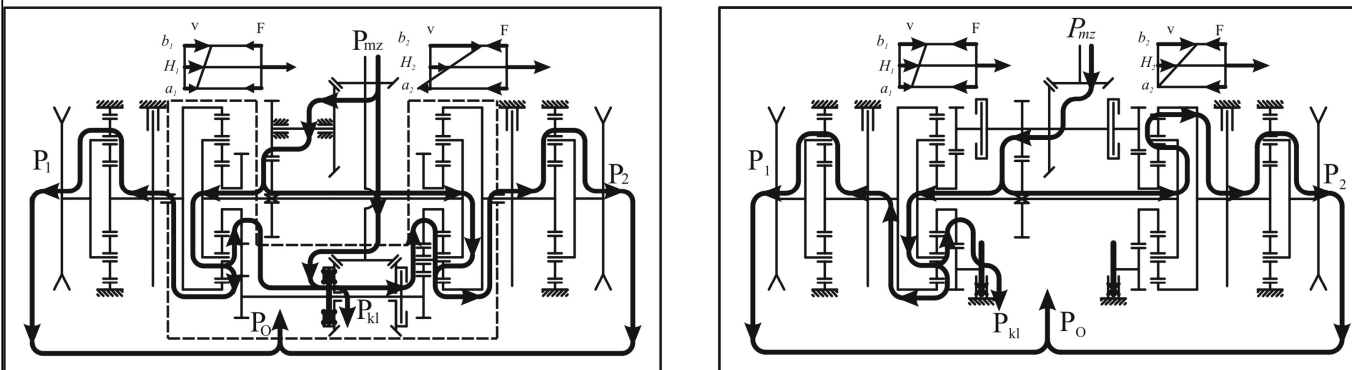

b) zaokret sa $R_{s}<R<\infty$
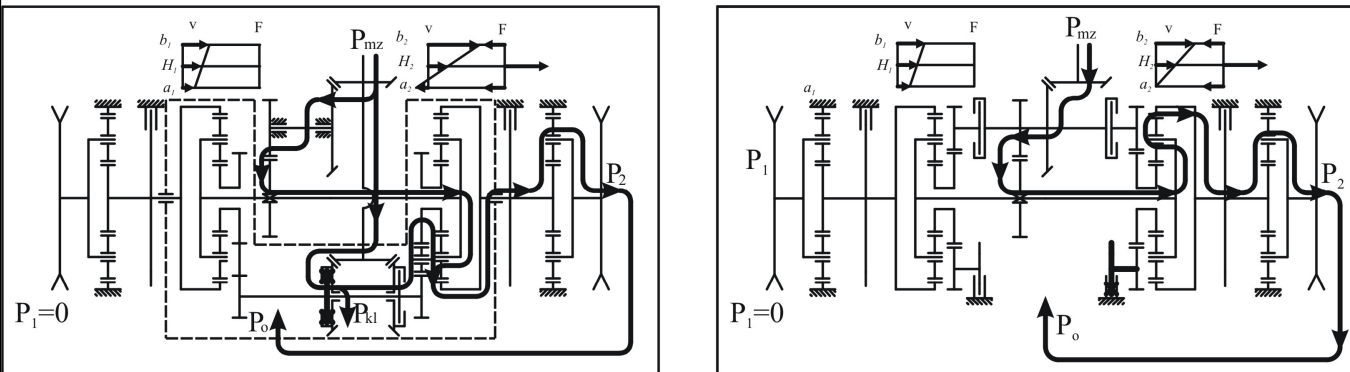

c) zaokret sa $R=R_{s}$

Sl. 8 - Tokovi snage u zaokretu 


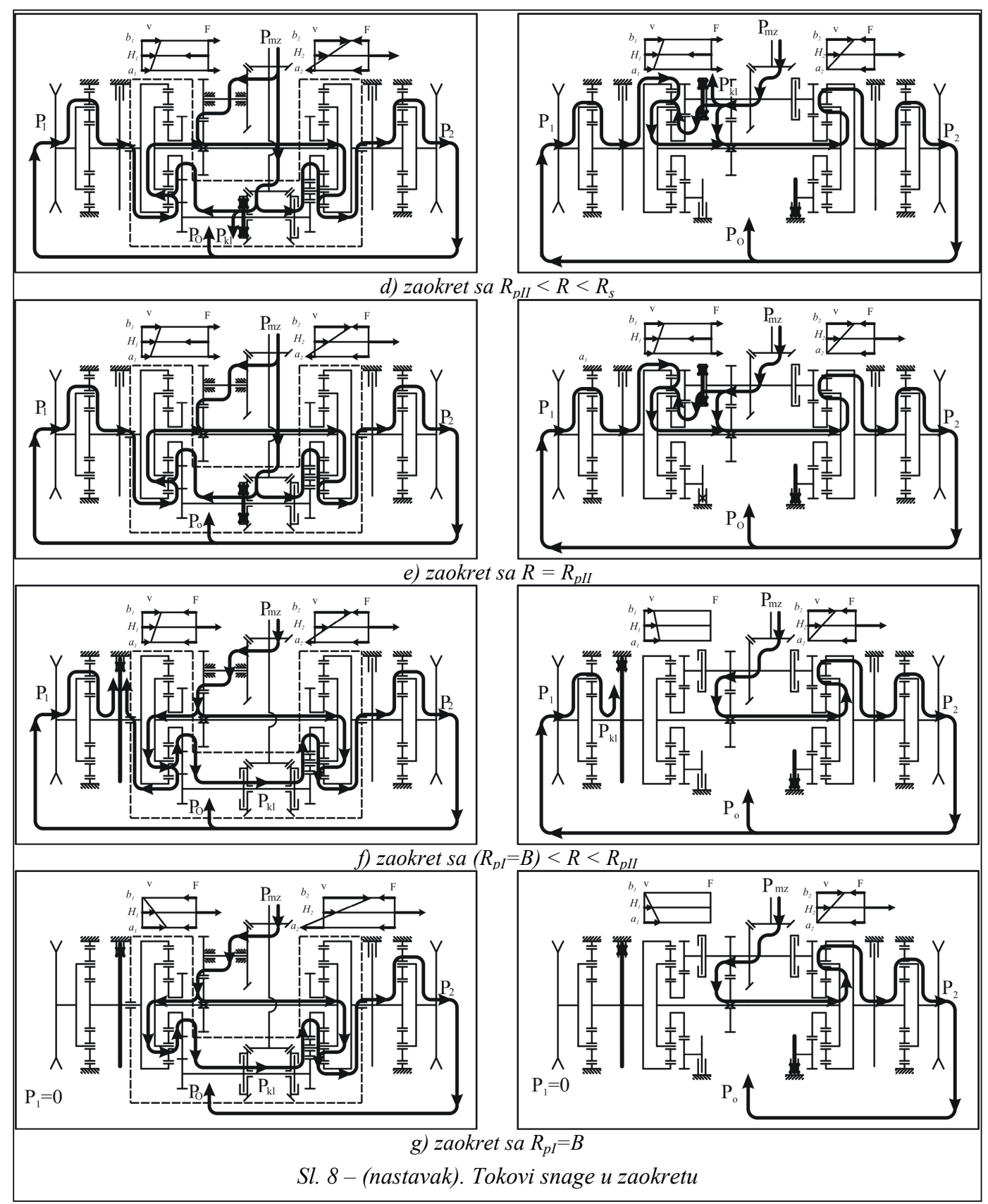

$\mathrm{Na}$ osnovu poznatih ugaonih brzina elemenata sistema za prenos snage i momenata na pripadajućim elementima moguće je odrediti i tokove snage unutar sistema. Određivanje tokova snage veoma je važno sa aspekta analize stepena korisnosti i opterećenja elemenata sistema za prenos snage. Na slici 8 prikazani su tokovi snage u svim funkcionalnim stanjima. 


\section{Rezultati proračuna i diskusija}

Da bi se sagledao odnos performansi zaokreta za razmatrane sisteme izvršen je proračun poluprečnika zaokreta $R_{p I I}$, snage klizanja i bilansa snage za razmatrane sisteme $u$ prvom i drugom stepenu prenosa. Pri izboru polaznih podataka vodilo se računa o tome da performanse pravolinijskog kretanja budu istovetne.

Promena proračunskih poluprečnika zaokreta prikazana je na dijagramu na slici 9.

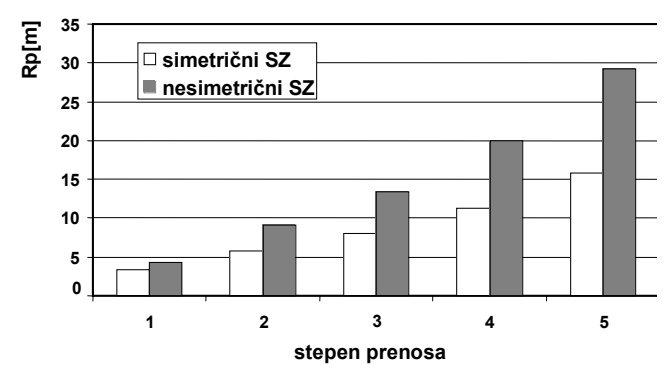

Sl. 9 - Promena proračunskog poluprečnika zaokreta u funkciji stepena prenosa
Dijagram pokazuje da su proračunski poluprečnici kod nesimetričnih sistema za zaokret veći nego kod simetričnih sistema. S obzirom na to da je zahtev da proračunski poluprečnik zaokreta bude u zoni u kojoj ne dolazi do bočnog klizanja zaključuje se da nesimetrični sistem ima bolji raspored proračunskih poluprečnika.

Zavisnost snage klizanja od poluprečnika zaokreta za razmatrane sisteme u I i II stepenu prenosa prikazana je na slici 10 .

$\mathrm{Na}$ osnovu dijagrama snage klizanja mogu se izvesti sledeći zaključci:

- snaga klizanja veća je kod simetričnih nego kod nesimetričnih sistema za zaokret;

- u području poluprečnika zaokreta između $\left(\mathrm{R}_{\mathrm{pI}}=\mathrm{B}\right)<\mathrm{R}<\mathrm{R}_{\mathrm{pII}}$ snaga klizanja kod nesimetričnih sistema veća je $\mathrm{u}$ odnosu na snagu klizanja pri drugim poluprečnicima (kod simetričnog sistema taj slučaj prisutan je u drugom i višim stepenima prenosa);

- u području poluprečnika zaokreta $\mathrm{R}>\mathrm{R}_{\mathrm{pII}}$ snaga klizanja sa povećanjem

Sl. 10 - Snaga klizanja

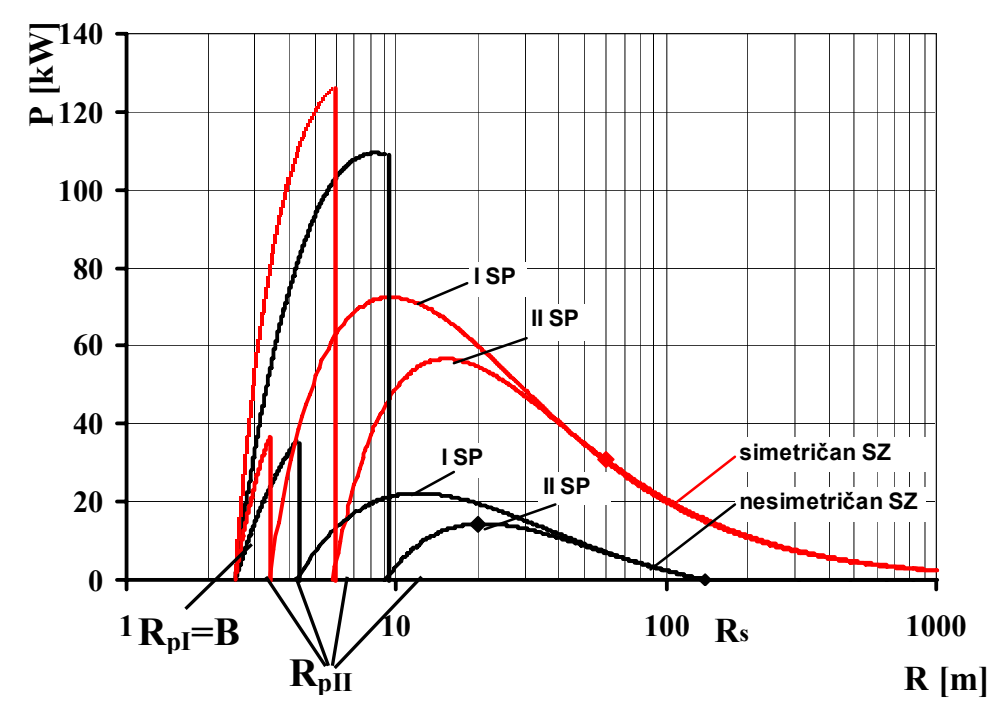


stepena prenosa se smanjuje, što ukazuje na činjenicu da je bolje iskorišćenje snage rekuperacije;

- u području poluprečnika zaokreta $\mathrm{R}>\mathrm{R}_{\mathrm{S}}$ snaga klizanja kod nesimetričnih sistema je praktično zanemarljiva.

Navedeni zaključci ukazuju na činjenicu da su sa aspekta snage klizanja povoljniji nesimetrični sistemi za zaokret. Takođe, u dijapazonu poluprečnika zaokreta $\mathrm{R}>\mathrm{R}_{\mathrm{pII}}$ nesimetrični sistemi rade sa dva frikciona elementa, što dodatno olakšava njihove uslove rada.

Mala snaga klizanja pri poluprečnicima zaokreta većim od $R_{S}$ takođe je povoljna, pošto u tim uslovima dolazi do čestog delimičnog aktiviranja frikcionih elemenata zbog korekcije pravca kretanja. Na dijagramima (slike 11 i 12) prikazan je bilans snage za prvi i drugi stepen prenosa.

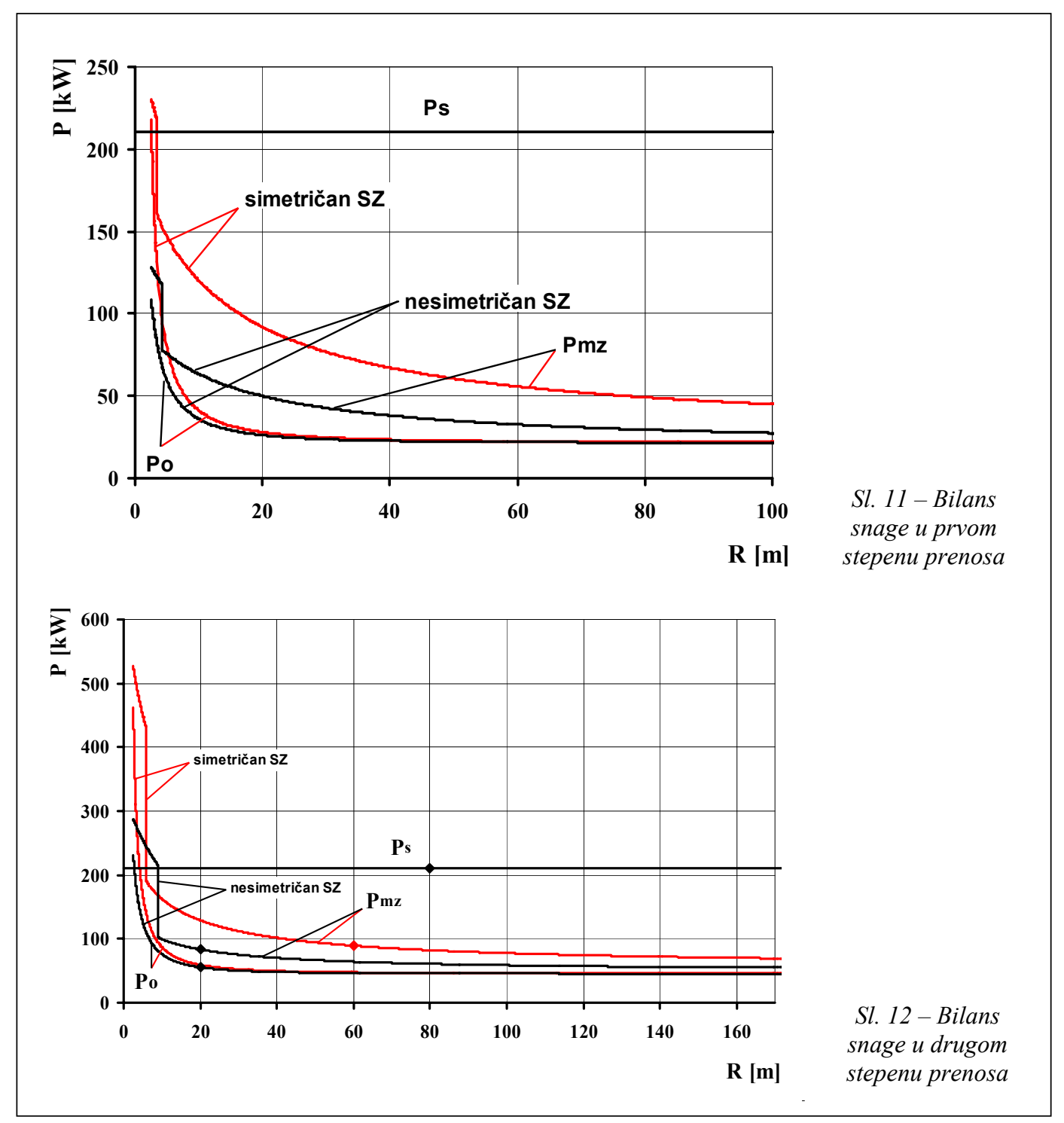


Dijagrami pokazuju da je snaga potrebna za savladavanje spoljašnjih otpora kod simetričnog sistema veća nego kod nesimetričnog, s tim da je razlika znatno veća kod manjih poluprečnika zaokreta. Sa povećanjem stepena prenosa potrebna snaga za izvođenje zaokreta raste, zbog povećanja brzine kretanja, tako da sa aspekta bilansa postoji veća mogućnost da vozilo neće biti u stanju da izvrši zaokret. Snaga motora potrebna za izvođenje zaokreta znatno je veća kod simetričnog sistema, tako da je moguće ograničavanje zaokreta i kod minimalnih poluprečnika i u prvom stepenu prenosa.

\section{Zaključak}

Prikazana analiza performansi zaokreta brzohodnih guseničnih vozila koja su opremljena sistemom za zaokret sa dva toka snage pokazuje da vučne performanse zaokreta bitno zavise od tipa sistema za zaokret. Analiza tokova snage $\mathrm{u}$ svim funkcionalnim stanjima bitna je sa aspekta detaljnijeg određivanja unutrašnjih gubitaka, što u radu nije preci- znije analizirano. S obzirom na bilans snage u zaokretu i gubitke snage u sistemu za zaokret prednost imaju nesimetrični sistemi. Međutim, njihov nedostatak je što pri zaokretu dolazi do smanjenja brzine kretanja, odnosno do narušavanja opštih performansi vozila. Dakle, pri izboru sistema za zaokret treba, pored performansi samog sistema, razmatrati i njegovo mesto u ostvarivanju funkcije cilja vozila kao celine, tako da izbor sistema za zaokret bude rezultat kompromisa koji treba da obezbedi najbolje ostvarivanje funkcije cilja.

\section{Literatura:}

[1] Dragojević, M.: Složeni sistemi prenosa snage kao osnovna komponenta u ostvarivanju optimalnih brzinskih i vučnih karakteristika i manevarskih sposobnosti savremenih guseničnih vozila domaćeg porekla, doktorska disertacija, TVA, Zagreb, 1974.

[2] Borbeno vozilo pešadije BVP M80A, tehničko uputstvo TU-I, 1583, SSNO, Beograd, 1989.

[3] Kovačič, B.: Teorija kretanja motornih vozila, Privredni pregled, Beograd, 1973.

[4] Muždeka, S., Pantić, M., Arsenić, Ž.: Vučne performanse zaokreta brzohodnih guseničnih vozila, 13. Međunarodni simpozijum MVM 2004, Kragujevac, 2004.

[5] Demić, M.: Osnovi teorije guseničnih vozila, Tehnički fakultet u Čačku, Kragujevac, 1992. 


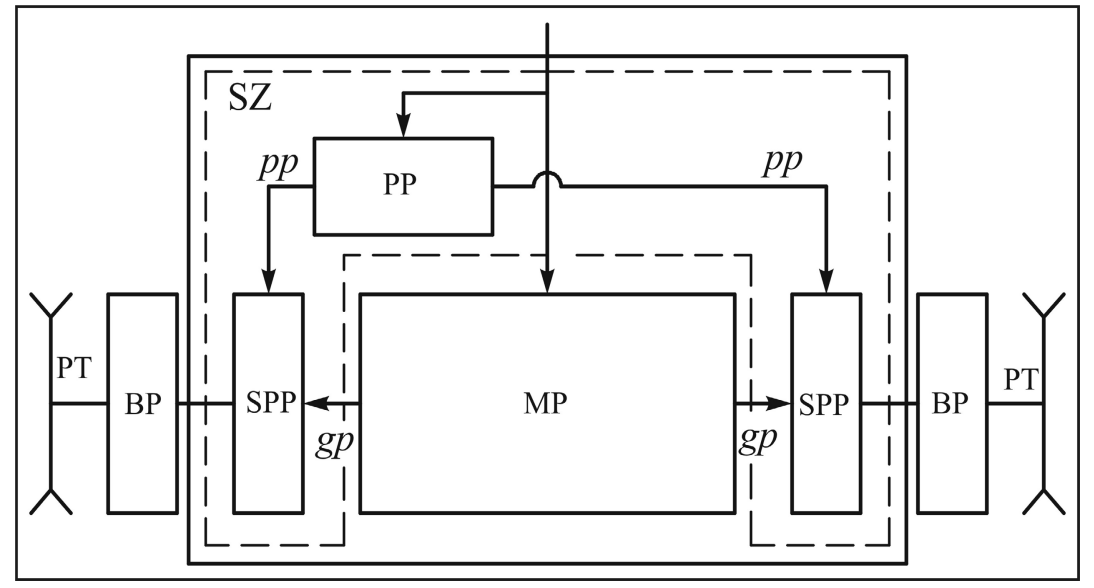

Sl. 1 - Blok-shema sistema za zaokret sa dva toka snage

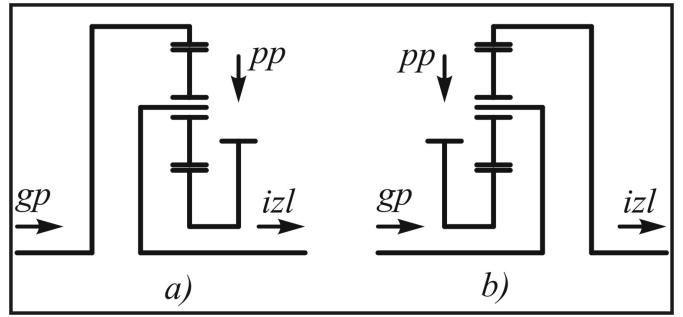

Sl. 2 - Najčešće kinematskekonfiguracije sumirajućeg planetarnog prenosnika

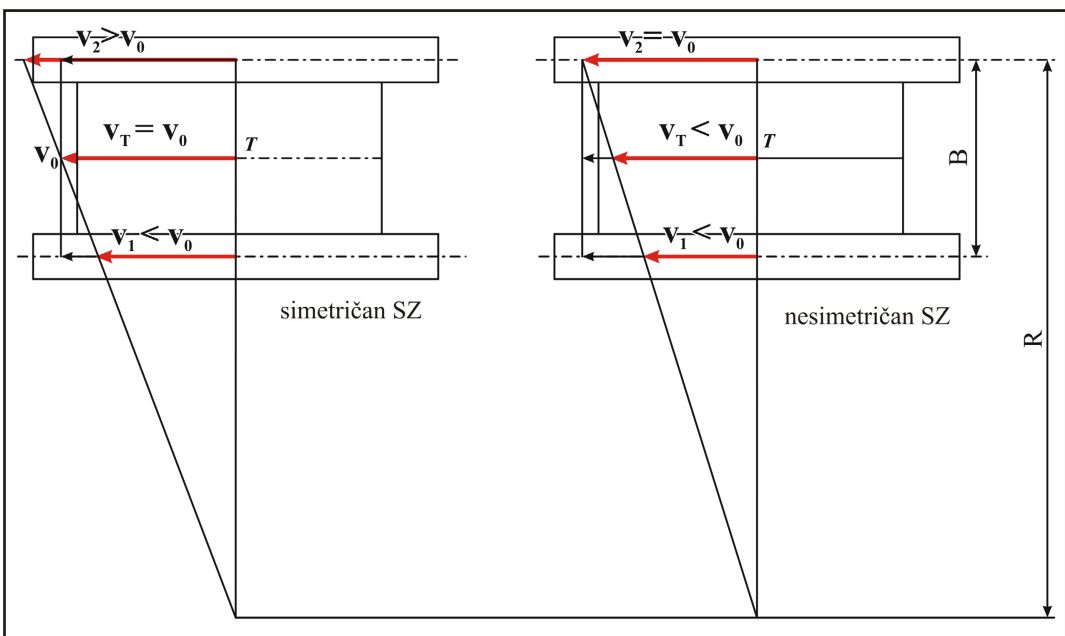

Sl. 3 - Brzine kretanja vozila u zaokretu

Tabela 1 
Brzine premotavanja gusenica

\begin{tabular}{|c|c|c|}
\hline Vrsta sistema & Nesimetričan & Simetričan \\
\hline $\begin{array}{c}\text { Brzina premotavanja unutrašnje } \\
\text { gusenice }\end{array}$ & $\mathrm{v}_{1}=\frac{\mathrm{R}-\mathrm{B}}{\mathrm{R}} \cdot \mathrm{v}_{0}$ & $\mathrm{v}_{1}=\mathrm{v}_{0} \cdot \frac{2 \cdot(\mathrm{R}-\mathrm{B})}{2 \cdot \mathrm{R}-\mathrm{B}}$ \\
\hline $\begin{array}{c}\text { Brzina premotavanja spoljašnje } \\
\text { gusenice }\end{array}$ & $\mathrm{v}_{2}=\mathrm{v}_{0}$ & $\mathrm{v}_{2}=\mathrm{v}_{0} \cdot \frac{2 \cdot \mathrm{R}}{2 \cdot \mathrm{R}-\mathrm{B}}$ \\
\hline
\end{tabular}
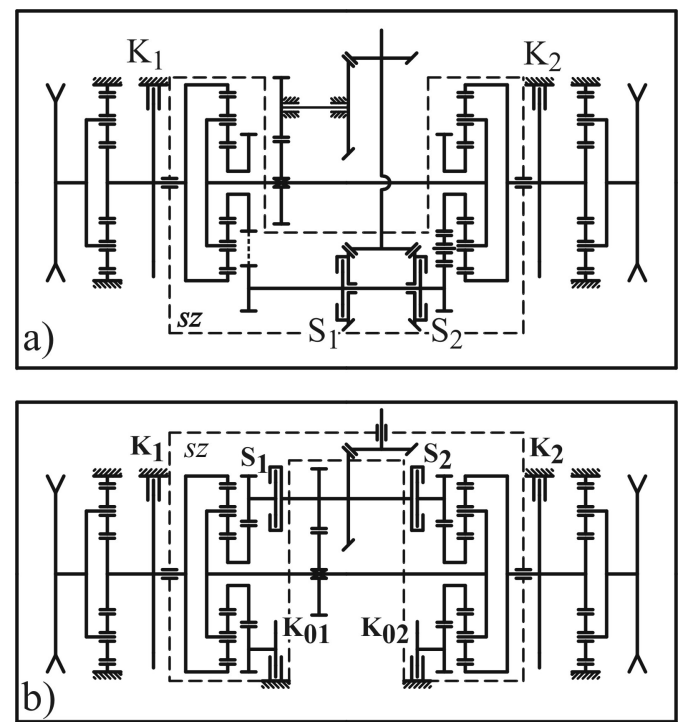

Sl. 4 -Kinematske konfiguracije razmatranih sistema za zaokret a) simetričan sistem; b) nesimetričan sistem 


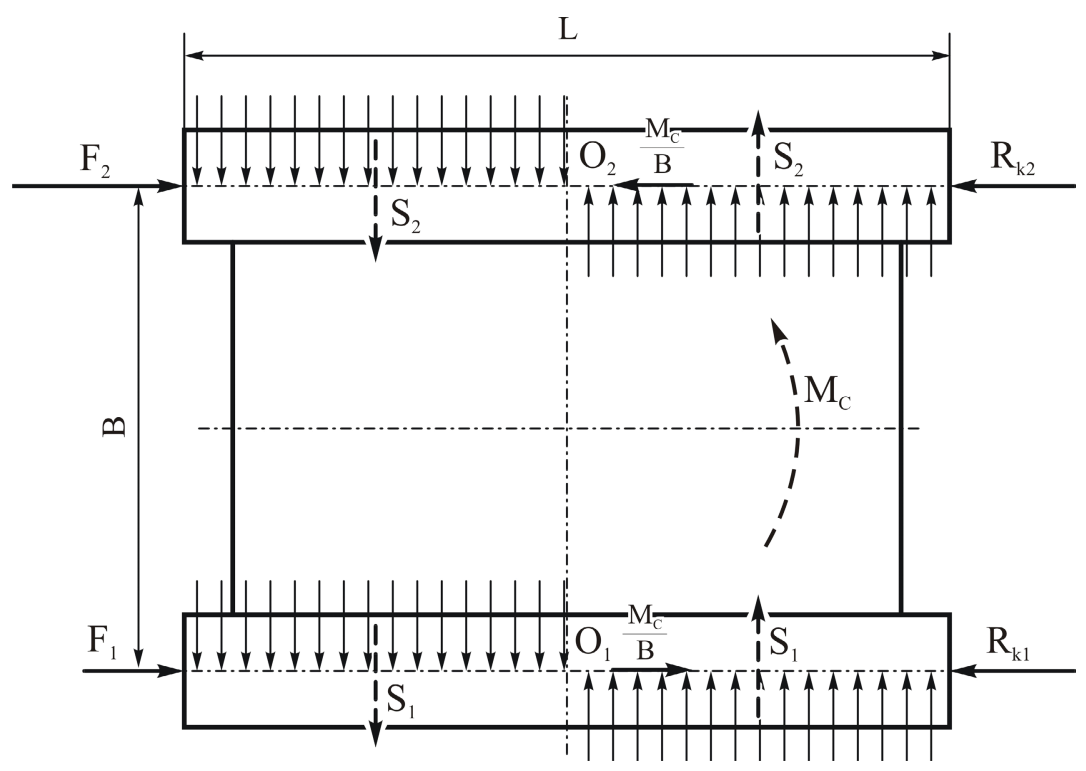

Sl. 5 - Sile koje deluju na gusenično vozilo u zaokretu

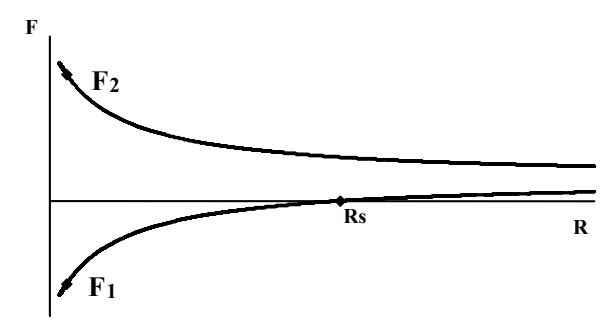

Sl. 6 - Potrebne sile na gusenicama pri izvođenju zaokreta

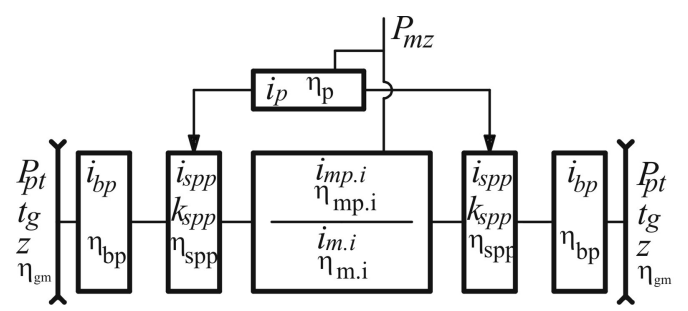

Sl. 7 - Parametri sistema za prenos snage

Proračunski poluprečnici zaokreta 


\begin{tabular}{|c|c|c|}
\hline Vrsta sistema & Nesimetričan & Simetričan \\
\hline Proračunski poluprečnik zaokreta & $\mathrm{R}_{\mathrm{PII}}=\frac{\left(1+\mathrm{k}_{\mathrm{spp}}\right) \cdot \mathrm{i}_{\mathrm{p}}}{\mathrm{i}_{\mathrm{m}}} \cdot \mathrm{B}$ & $\mathrm{R}_{\mathrm{PII}}=\frac{\left(1+\mathrm{k}_{\mathrm{spp}}\right) \cdot \mathrm{i}_{\mathrm{p}}+\mathrm{i}_{\mathrm{m}}}{2 \cdot \mathrm{i}_{\mathrm{m}}} \cdot \mathrm{B}$ \\
\hline
\end{tabular}

$\mathrm{P}_{k l}= \begin{cases}\frac{1}{i_{p} \cdot \eta_{p} \cdot \eta_{b p}} \cdot\left(\frac{F_{2}}{\eta_{g m .2}}-\frac{F_{1}}{\eta_{g m .1}}\right) \cdot\left(\frac{i_{m}}{1+k_{s p p}}-i_{p} \cdot \frac{B}{2 \cdot R-B}\right) \cdot v_{0}, & \text { za } R>R_{P} \\ \frac{F_{1} \cdot \eta_{m}}{\eta_{t r} \cdot \eta_{g m .1}} \cdot \frac{2 \cdot(R-B)}{2 \cdot R-B} \cdot v_{0}, & \text { za } B<R<R_{P}\end{cases}$

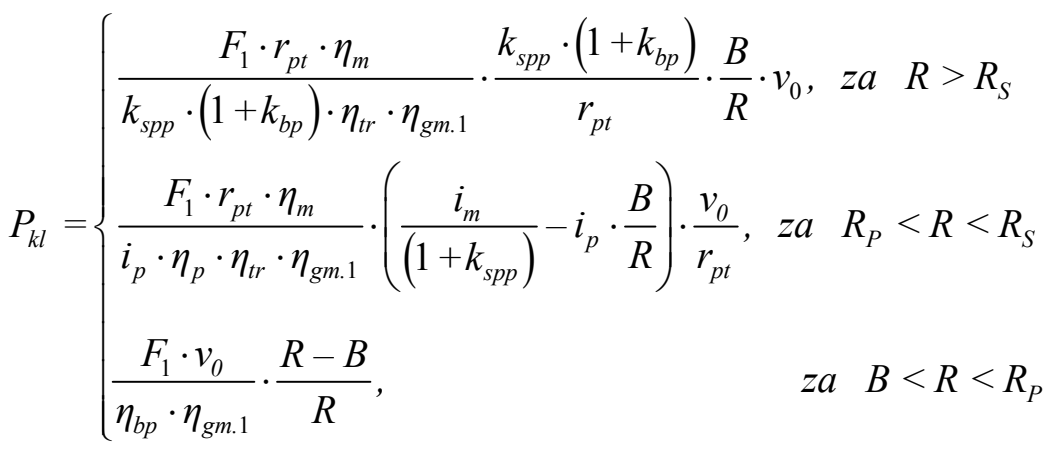

$P_{m z}= \begin{cases}\frac{v_{0}}{\eta_{t r}} \cdot\left(\frac{F_{2}}{\eta_{g m .2}}+\frac{F_{1}}{\eta_{g m .1}}\right)+\frac{i_{m} \cdot \eta_{m}}{\left(1+k_{s p p}\right) \cdot i_{p} \cdot \eta_{p} \cdot \eta_{t r}} \cdot\left(\frac{F_{2}}{\eta_{g m .2}}-\frac{F_{1}}{\eta_{g m .1}}\right) \cdot v_{0}, & \text { za } \quad R>R_{P} \\ \frac{1}{\eta_{t r}} \cdot\left(\frac{\left|F_{1}\right|}{\eta_{g m .1}}+\frac{F_{2}}{\eta_{g m .2}}\right) \cdot v_{o}, & \text { za } B<R<R_{P}\end{cases}$

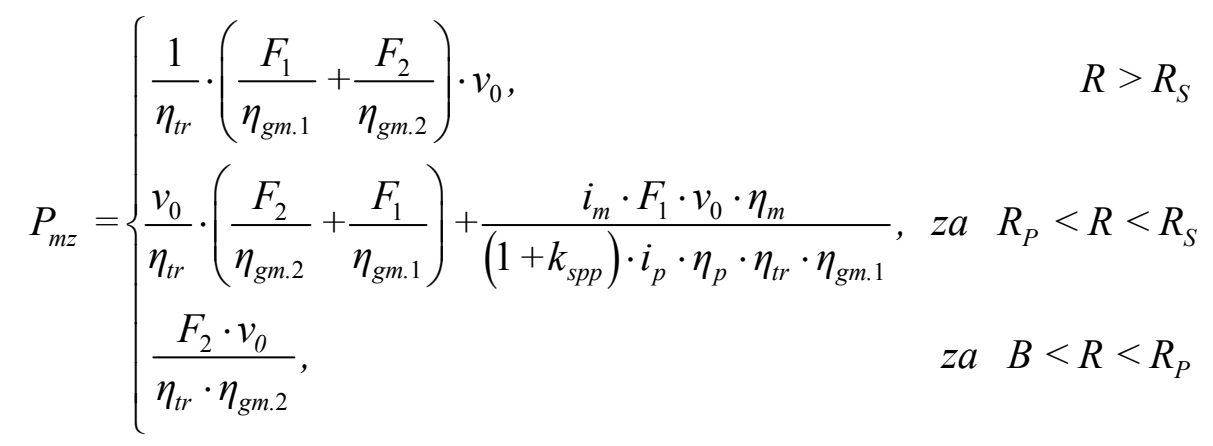



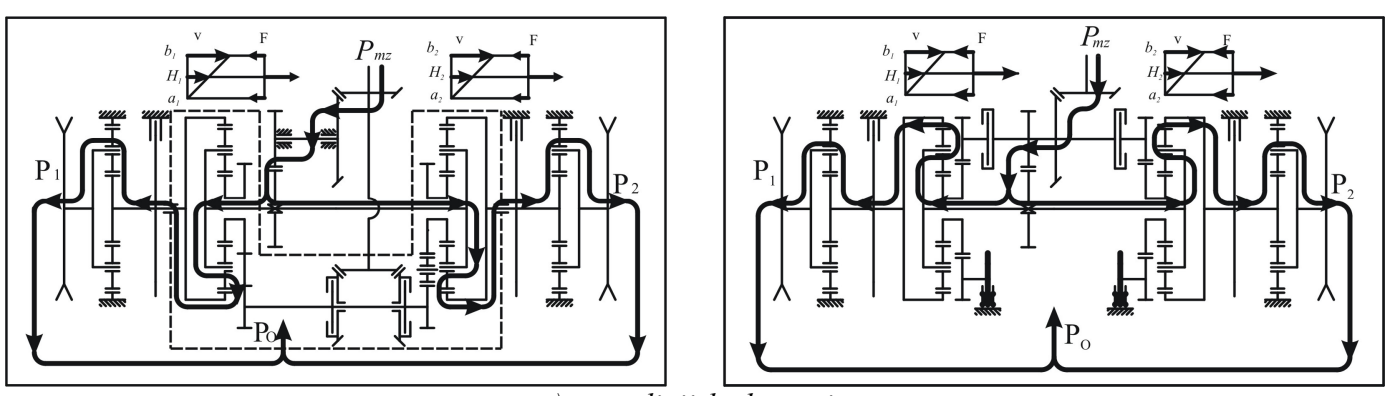

a) pravolinijsko kretanje
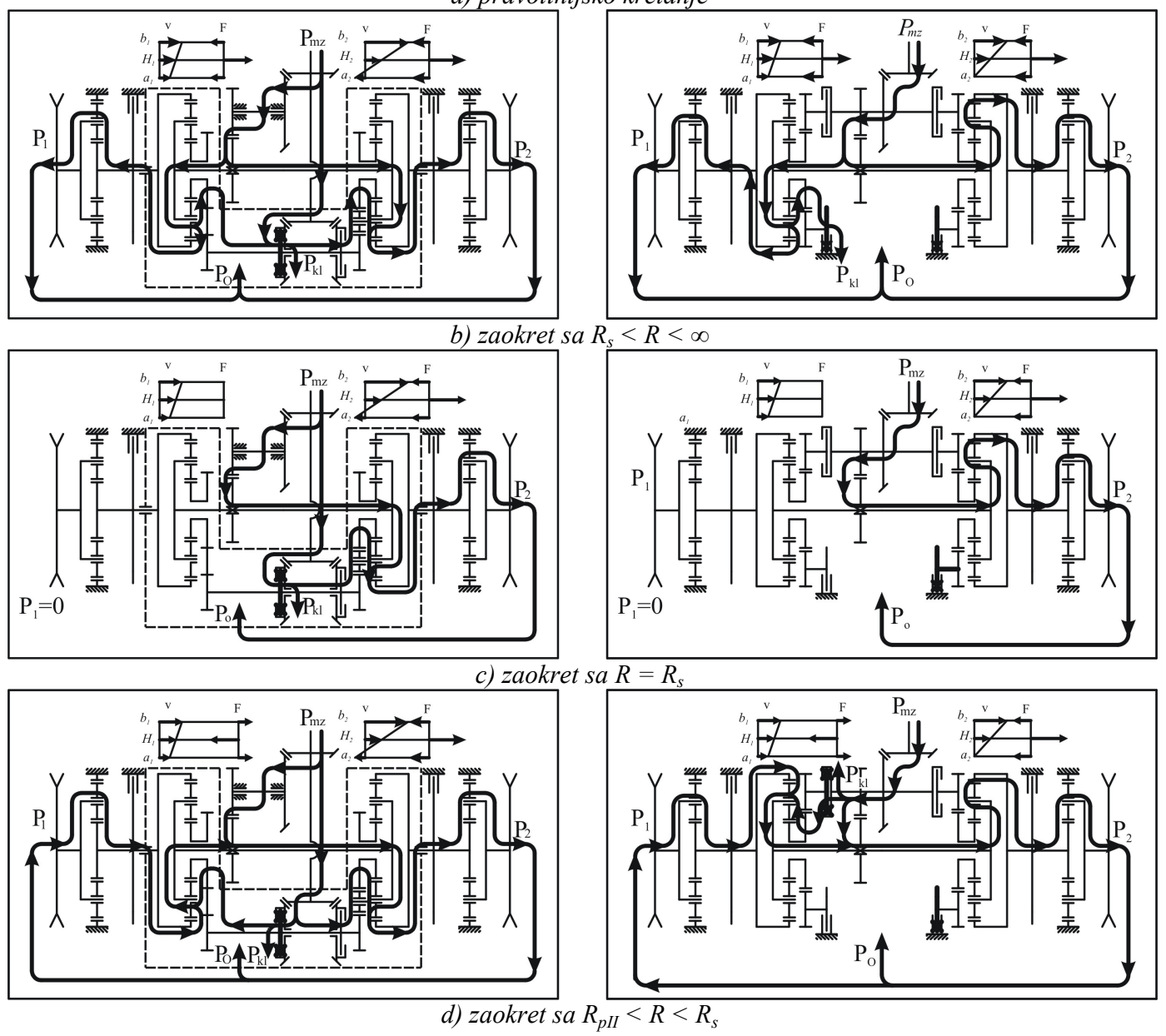

Sl. 8 - Tokovi snage u zaokretu 

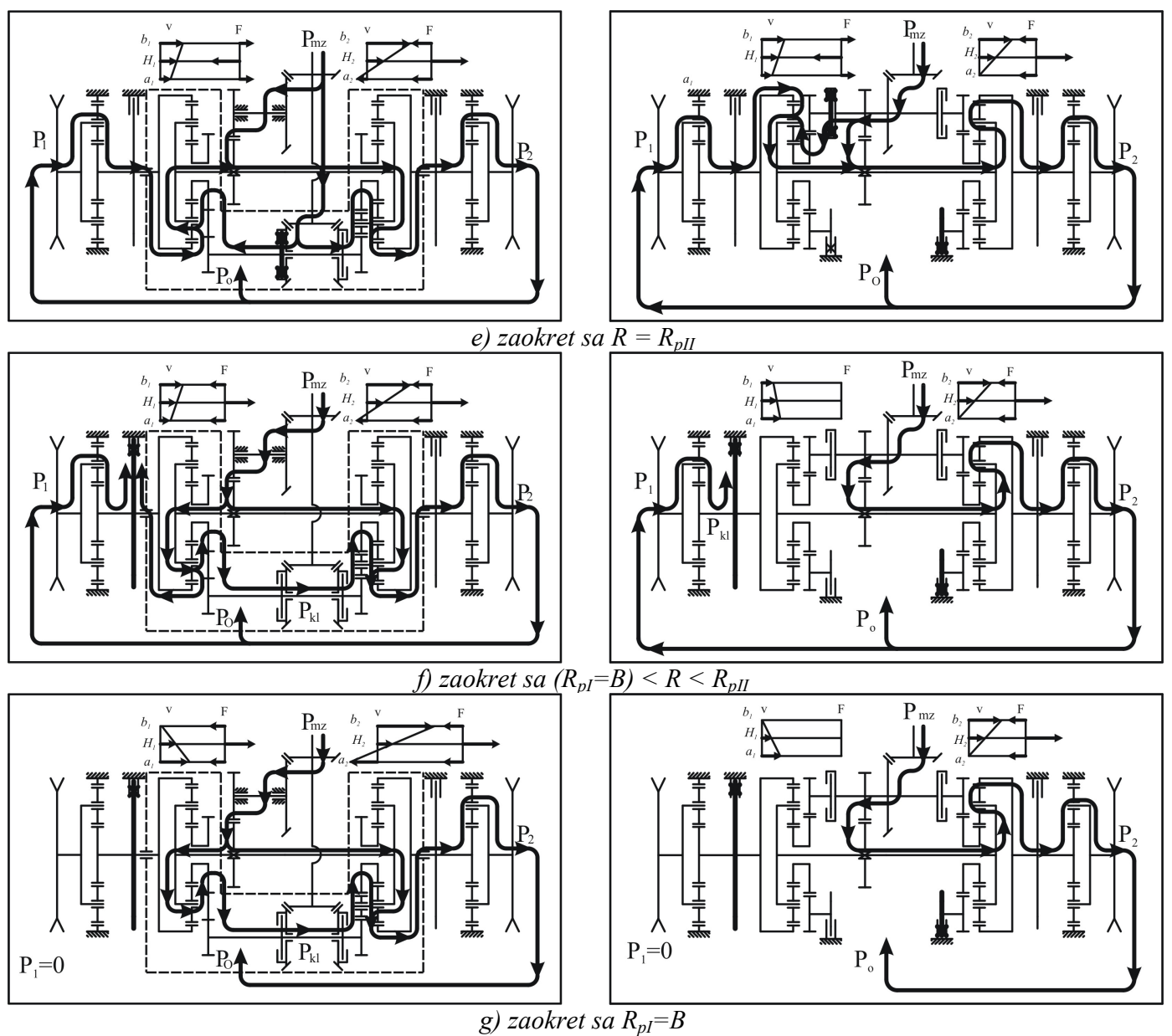

Sl. 8 (nastavak). Tokovi snage u zaokretu

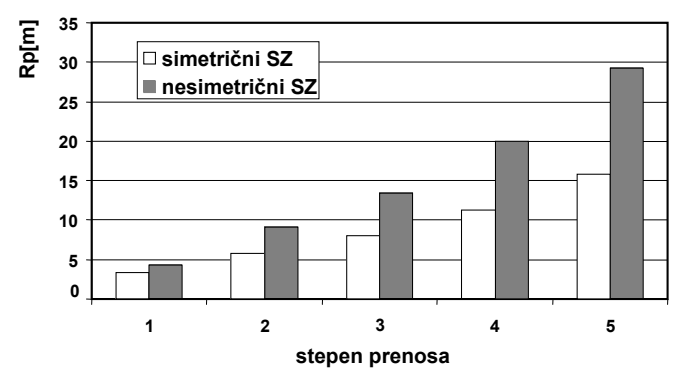

Sl. 9 - Promena proračunskog poluprečnika zaokreta u funkciji stepena prenosa 


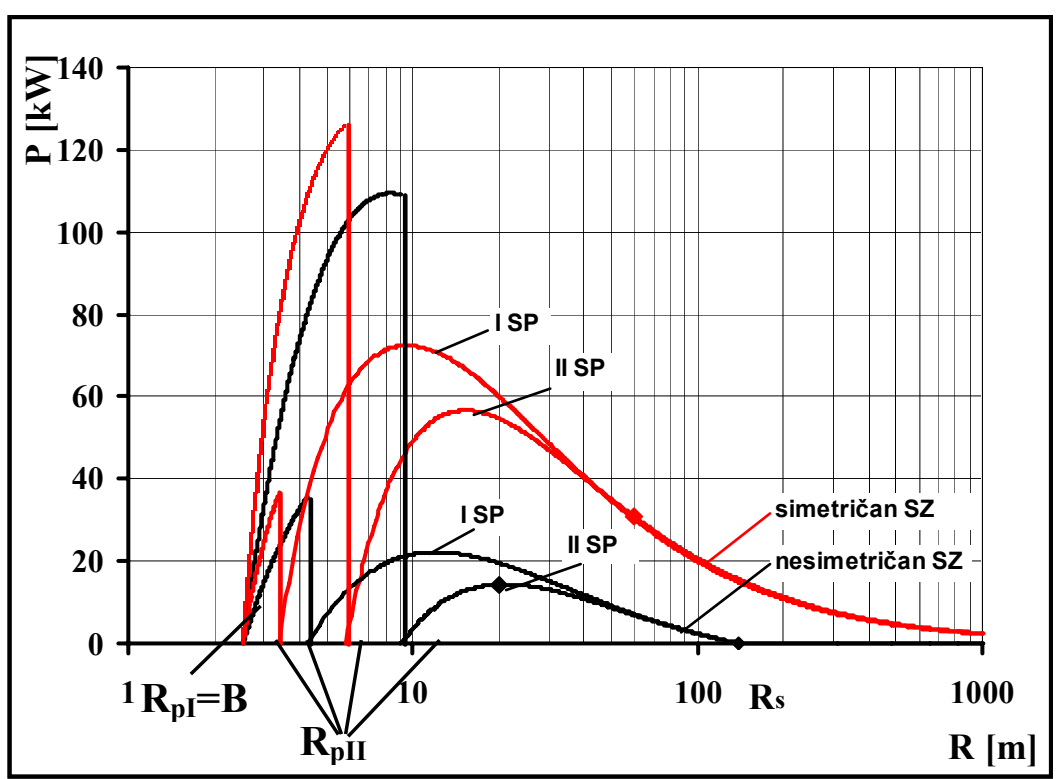

Sl. 10 - Snaga klizanja

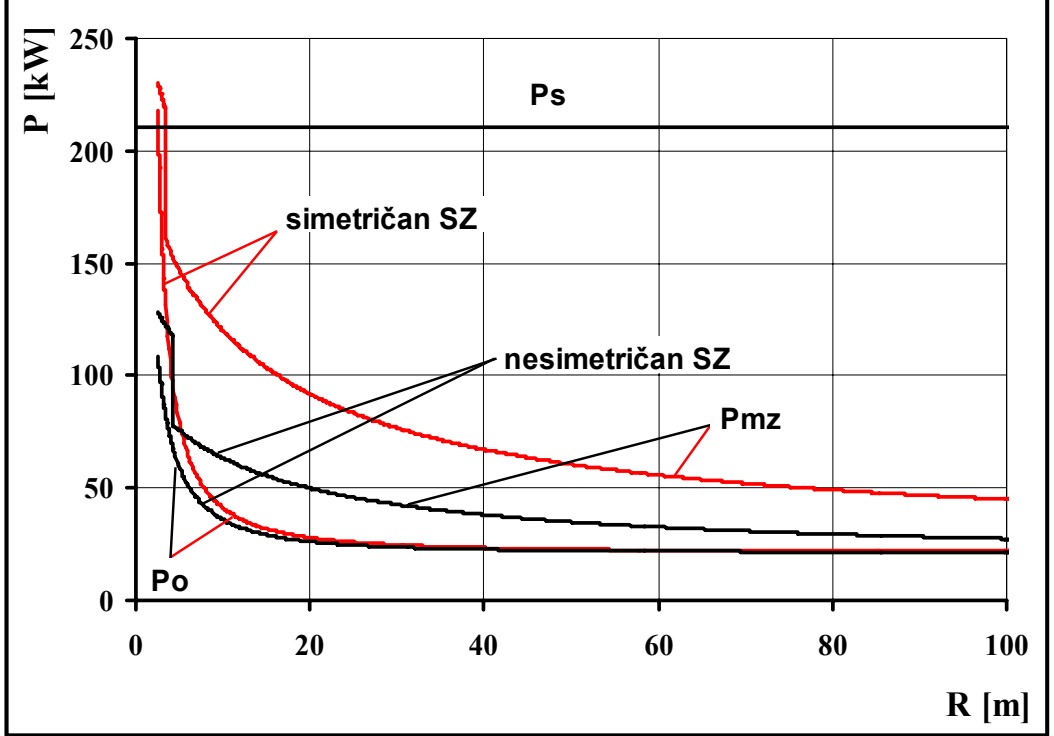

Sl. 11 - Bilans snage u prvom stepenu prenosa 


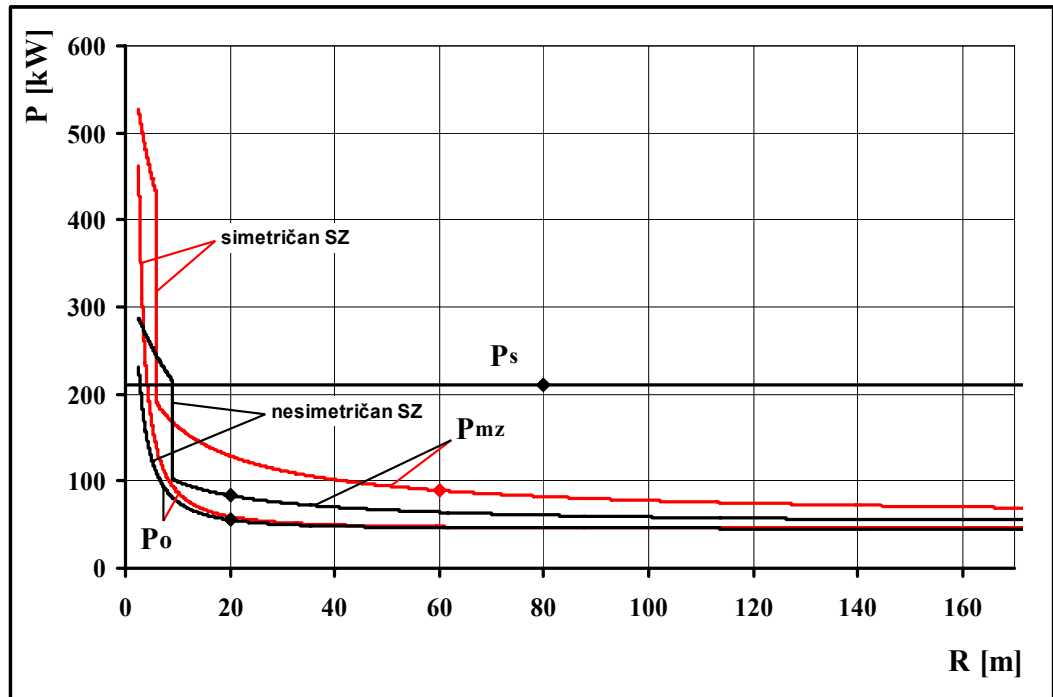

Sl. 12 - Bilans snage u drugom stepenu prenosa 